\title{
O FEMINIZMU U UVODNICIMA ČASOPISA "PROFEMINA"
}

Cilj ovog rada jeste da opiše odnos časopisa ProFemina, odnosno njegovih urednica, saradnica i saradnika prema feminizmu. Rad se bavi značenjem pojmova "feminizam" i "žensko" u uvodnicima ProFemine, kao i u samom podnaslovu časopisa. Analiziraju se uvodnici iz svih brojeva časopisa, sa posebnim fokusom na onima iz prvog broja: razmatra se kako urednice Svetlana Slapšak, Radmila Lazić, Ljiljana Đurđić i Dubravka Đurić razumeju "feminizam" i "žensko". Stavovi izneti u uvodnicima, kao i nastanak časopisa, stavljeni su u širi kontekst društvenih $\mathrm{i}$ istorijskih prilika. Na osnovu uređivačke politike časopisa, kao i okolnosti u kojima on izlazi, može se zaključiti da specifičan odnos prema feminizmu ima za cilj da do tada marginalizovano autorstvo učini vidljivim, kako osvajanjem tako i menjanjem javnog prostora.

Ključne reči: ProFemina, feminizam, ženska književnost, uređivačka politika 


\section{UVOD}

Jedno od pitanja koje se nameće nekome ko se prvi put bavi analizom periodike jeste - čemu studije periodike, zašto su one važne? Šta periodiku čini zanimljivim izvorom informacija? Da li i kako periodika svedoči o određenim društvenim i kulturnim prilikama? Ali, isto tako, da li je i na koji način periodika imala uticaja na te prilike? U načelu, moglo bi se reći da periodika, zbog kontinuiranog i ponekad dugotrajnog izlaženja, pruža uvid u trenutno stanje određene (naučne, kulturne, društvene...) oblasti kojom se bavi, kao i svojevrsni istorijat razvoja te oblasti. Međutim, istinski značaj neke periodične publikacije moguće je sagledati samo u konkretnom kontekstu u kom je ona nastala, potom objavljivana, te (u nekim slučajevima) ugašena. Kako Manušag Pauel (Manushag Powell) kaže: "U sastavljanju serijske publikacije učestvuju svi mogući tipovi saradnika, a konzumiraju je svi mogući tipovi čitalaca." Zbog brojnosti saradnika, njihovih međusobnih razlika, kao i zbog raznovrsnosti priloga u jednom časopisu, neretko se javljaju kontradiktornosti u stavovima koje navode istraživačice i istraživače periodike da se uzdrže od bilo kakvih generalizacija i donošenja izričitih zaključaka. Pauel s pravom tvrdi: "Za skoro svaku generalizaciju o tome šta periodika 'čini' moguće je naći neosporive primere u kojima ona čini nešto potpuno suprotno.”2

Imajući to $u$ vidu, u ovom radu razmatram šta znači feminizam (kao reč, pojam, ideologija, pokret...) u kontekstu časopisa ProFemina. Još preciznije, zanima me kakav se odnos prema feminizmu artikuliše u uvodnicima u ovom časopisu. Kako bih sagledala taj odnos, ispitaću sličnosti i razlike u značenju pojmova žensko i feminističko, o kojima se raspravljalo i u časopisu ProFemina. Postaviću sledeća pitanja: U čemu je razlika između ženskog i feminističkog? Da li je cilj ProFemine uključivanje u postojeći javni prostor ili stvaranje novog prostora? Da li se ProFemina zalaže za jednakost ili insistira na razlici? Da li ProFemina nudi znanja koja nedostaju na univerzitetu? Da li ovaj časopis proizvodi feminističko/žensko znanje?

Uvodnici se obično bave promenama u uredničkoj politici, kao i razmatranjem kontroverznih političkih dešavanja, čime uredništvo zauzima jasan politički stav. U ovom radu posebnu pažnju posvetila sam uvodnicima objavljenim u prvom broju časopisa. Nekoliko je razloga za to. U prvom broju oglasile su sve četiri urednice. Drugo, uvodnici iz prvog broja predstavljaju važne komunikacijske tekstove

1 Manushag N. Powell, "Afterword: We Other Periodicalists, or, Why Periodical Studies?”, Tulsa Studies in Woman's Literature, Vol. 30, No. 2, Fall 2011, 441.

2 Ibid. 
jer se u njima iznose program i urednička politika časopisa, kao i politički/vrednosni stavovi u specifičnom istorijskom trenutku. Naime, ProFemina je pokrenuta u vreme oružanih sukoba na prostoru Jugoslavije. Dominantna orijentacija ovog časopisa bila je pacifistička i feministička. Uvodnici su bili "eksplicitno politički, osuđivali su nacionalizam i fašizam, zalagali se za mirovnjačke političke opcije, osuđivali su mizoginiju, rasizam, mačizam itd." ${ }^{3} \mathrm{U}$ tom smislu, oni su primer za antiratni feminizam, insistiranje na odgovornosti i feminističkoj solidarnosti.

\section{ISTORIJSKI KONTEKST U KOM NASTAJE ČASOPIS "PROFEMINA"}

ProFemina, časopis za žensku književnost i kulturu nastaje 1994. godine u Beogradu, na inicijativu Sonje Liht i Verana Matića. ${ }^{4}$ Izdavač je bio B92, a pokrovitelj Soros fond Jugoslavije. ${ }^{5}$ Glavna i odgovorna urednica do poslednjeg broja, Svetlana Slapšak, napisala je najveći broj uvodnika. ${ }^{6}$ Da bismo razumeli stavove iznete u uvodnicima ProFemine, neophodno je sagledati širi kontekst, odnosno društvene i političke prilike u kojima se osniva časopis. U trenutku kada je izašao prvi broj, u zimu 1994/95. godine, građanski rat u Jugoslaviji još nije završen, sankcije međunarodne zajednice još nisu ukinute, $\mathrm{u}$ toku je hiperinflacija. Osim toga, u javnosti preovlađuje izrazito nacionalistička i militantna politika, kao i jak etnonacionalistički diskurs. U Srbiji, takvo stanje u društvu dovodi do izolacije zemlje, kao i do porasta nasilja i organizovanog kriminala. Velik broj uglavnom mladih i obrazovanih ljudi odlazi u inostranstvo. S druge strane, u Srbiju dolaze izbeglice koje napuštaju svoje domove u Hrvatskoj i Bosni i Hercegovini. U tom trenutku, jedini koji donekle "popravljaju" sliku o Srbiji jesu aktivisti/kinje, borci/kinje za ljudska prava i slobodu, odnosno antiratne organizacije. Oni su, kako primećuje Svetlana Slapšak, "za zemlju obavili dragocenu funkciju neutralizacije i uveravanja stranih sila da ima normalnih ljudi, i da treba nahraniti, pomoći, ne

3 Dubravka Đurić, "Feministički i ženski časopisi u postjugoslovenskim kulturama”, ProFemina, specijalni broj, leto-jesen 2011, 270.

4 Svetlana Slapšak, "Deset godina ProFemine", ProFemina, broj 35/36, proleće/ leto 2004, 11.

5 Od 1996. godine, Fond za otvoreno društvo.

6 Više o časopisu vidi u: Jelena Milinković, "ProFemina: interkulturalizam i jugoslovenski feminizmi”, u: Drago Roksandić, ur., Hrvatsko-srpski/srpsko-hrvatski interkulturalizam danas (Zagreb: Filozofski fakultet Sveučilišta u Zagrebu, 2017), 127-138. 
napasti i pustiti da žive oni sasvim drugčijeg mišljenja i ponašanja."7 Međutim, te iste aktivistkinje i aktivisti, koji se prvenstveno zalažu za mir i okončanje sukoba, u Srbiji imaju negativnu reputaciju i etiketirani su kao "izdajice nacije" i "antiratni profiteri”. Svetlana Slapšak napade na žene i pacifiste i izmišljanje kategorije "antiratni profiteri” tumači kao pokušaj prepravljanja istorije i uništavanja prošlosti, u cilju da se zabrani pristup pamćenju, "neprijatelji se određuju kao oni koji pamte, povezuju, dobijaju i dele informacije, kao 'mundijalisti' ili naprosto kao špijuni”. 8

Treba napomenuti da njihova reputacija nije znatno drugačija ni po završetku rata. To vidimo i u uvodniku časopisa ProFemina iz 1997. godine: "Mlad mir doneo je očekivanu netrpeljivost prema svima koji su još podsećali na rat: pacifistima, ženama, kritičarima, svima koji su se ikad oglasili protiv." 9 Naime, dominantni diskurs je i dalje nacionalistički, jer je ista politička struktura i dalje na vlasti. Svi oni koji pozivaju na prihvatanje kolektivne odgovornosti za počinjena nedela smatraju se izdajnicima nacionalnog interesa. Postojanje alternativnog narativa, odnosno suočavanje sa zločinom, razgovor o zločinu i njegova osuda, kao i bavljenje prošlošću uopšte, ključno je za prevazilaženje ratnog stanja. Po mišljenju Nenada Dimitrijevića, "odbijajući da se suočimo sa zločinima i njihovim posledicama, mi biramo da ostanemo u ratnom stanju". ${ }^{10} \mathrm{U}$ tom i takvom kontekstu, od značaja je istupanje svih onih u čije ime je vođen rat, a koji o ratu nisu odlučivali. Zauzimanjem antiratnog stava, građani preuzimaju na sebe ulogu koju bi trebalo da obavljaju određene institucije (izneveravajući tu ulogu, te institucije poriču prošlost i odbijaju da se sa njom suoče).

Zato ne čudi da je upravo prva polovina devedesetih godina dvadesetog veka period u kom se formira velik broj nevladinih, aktivističkih grupa i organizacija. U njihovom fokusu su oni segmenti stvarnosti koje dominantni diskurs ignoriše. Pored antiratnog delovanja, te organizacije se bave i osnaživanjem žena, daju podršku žrtvama nasilja, promovišu žensku književnost i kulturu, feminističku teoriju i aktivizam. Tako se 1990. godine osniva prva ženska politička stranka u Srbiji - Žest, kao i prvi SOS telefon za podršku žrtvama nasilja.

7 Svetlana Slapšak, "Postavimo granice”, ProFemina, broj 11, jesen 1997, 11-14.

8 Ibid.

9 Svetlana Slapšak, "Polites, Patriotes”, ProFemina, broj 9/10, zima/proleće 1997, 11-12.

10Nenad Dimitrijević, "Moralne osnove izgradnje mira”, u: Reč, časopis za književnost $i$ kulturu, $i$ društvena pitanja, broj 87/33, 2017, 7. 
Žene u crnom 1991. godine počinju s radom. Centar za ženske studije, osnovan 1992. godine, pokreće časopis Ženske studije u zimu 1994/1995. Iste godine osniva se i časopis ProFemina, dok prvi broj Feminističkih svezaka izlazi nešto ranije, u izdanju Autonomnog ženskog centra. ${ }^{11}$ Te ženske i feminističke inicijative, deo feminističkog pokreta, bile su antiratno orijentisane, imale su nedvosmislen odnos prema odgovornosti i izraženu težnju ka solidarnosti i internacionalnosti. Takođe, takve inicijative su morale da zauzmu kritički i jasan stav prema državi koja je propagirala sve suprotno - rat, izbegavanje ili negiranje odgovornosti, nacionalizam, i koja ih je proglasila "državnim neprijateljima", "stranim plaćenicima" $i$ "antiratnim profiterima”. ProFemina takođe predstavlja alternativu zvaničnoj kulturi. U uvodniku povodom sedmogodišnjice izlaženja časopisa, Svetlana Slapšak ga opisuje kao drugo:

Drugo je u svakoj kulturi ključno za razumevanje prvoga, zvaničnoga, prihvaćenoga, main-streama, analiza drugoga često otkriva prave razloge naizgled nerazumljivih kulturnih pojava povlašćenije oblasti. Stoga je postupak posmatranja i ispitivanja drugoga ne samo legitiman nego i neophodan za razumevanje celine. U tome smislu, položaj ProFemine i njenih autorki/autora nudi se analizi, ne samo zbog prvih sedam godina... ${ }^{12}$

\section{“PROFEMINA, ČASOPIS ZA ŽENSKU KNJIŽEVNOST I KULTURU": U ČEMU JE RAZLIKA IZMEĐU ŽENSKOG I FEMINISTIČKOG?}

Pojmovi "žensko" i "feminističko" svakodnevno se koriste u različitim kontekstima, implicitnim i eksplicitnim značenjima, sa pozitivnim i negativnim konotacijama. S obzirom na to da su ovi pojmovi višeznačni, te da je teško dati jednu ispravnu definiciju oko koje bi se svi složili, pre nego što počnem sa razmatranjem razlike između "ženskog" i "feminističkog" u časopisu ProFemina, definisaću šta podrazumevam pod tim pojmovima.

Da bih opisala konkretne artikulacije feminizma u časopisu ProFemina, poslužiću se najpre širom definicijom koja podrazumeva

11 Više o ženskom pokretu devedesetih godina dvadesetog veka vidi u: Marina Blagojević, prir., Ka vidljivijoj ženskoj istoriji. Ženski pokret u Beogradu 9o-ih (Beograd: Centar za ženske studije, istraživanja i komunikaciju, 1998).

12 Svetlana Slapšak, "Procenjivanje, o sedmogodišnjici”, ProFemina, broj 27/28, jesen/zima 2001, 13. 
feminizam kao delovanje u cilju promene kulturnih modela koji diskriminišu ono što nije dominantno:

Feminizam - kao i mnogi drugi -IZMI - jeste pokret, ideologija, lično uverenje, mreža teorijskih pozicija, polazna tačka u razmatranju fenomena koji se više ni ne moraju ticati žena, pojmovni okvir, skup različitih (ponekad izrazito kreativnih, ponekad teskobno arhivarskih) aktivnosti čiji je cilj pospešenje položaja u kojem se žene danas nalaze, a neretko i pokušaj da se istorija pročita drugačije, da se iz njenog tkanja "izvuku" neka nevidljiva mesta koja bi mogla da posluže kao putokaz za buduće prakse. ${ }^{13}$

Pojam “ženskog", kao i odnos “ženskog" i "feminističkog”, složen je. Ako feminizam shvatimo kao zalaganje za poboljšanje položaja žena i ostalih marginalizovanih grupa, onda možemo da zaključimo da činjenica da je neko žensko ne podrazumeva da je ta osoba i feministkinja. Feminizam se zalaže za "borbu protiv svih oblika patrijarhata i seksizma", ${ }^{14}$ dok je samo žensko stvaralaštvo često patrijarhalno i u skladu sa dominantnim kulturnim modelima. Pa ipak, ova dva pojma se često mešaju. Kao primer, Toril Moi u svom tekstu "Feminističko, žensko, ženstveno" objašnjava čestu pretpostavku da je svako opisivanje ženskog iskustva izričito feministički čin:

S jedne strane to je zaista tačno: pošto je patrijarhat oduvek pokušavao da utiša i potisne žene i žensko iskustvo, učiniti ih vidljivim svakako je važna anti-patrijarhalna strategija. S druge strane, žensko iskustvo može biti učinjeno vidljivim na otuđujući, obmanjujući ili ponižavajući način (...). ${ }^{15}$

U tom smislu, različitim ženskim iskustvima može se pristupiti sa stanovišta feminizma, ali žensko iskustvo samo po sebi ne mora biti feminističko, niti je svaka njegova interpretacija nužno feministička.

13 Adriana Zaharijević, “Kratika istorija sporova: šta je feminizam?”, u: Adriana Zaharijević, prir., Neko je rekao feminizam? Kako je feminizam uticao na žene XXI veka (Beograd: Heinrich Böll Stiftung, Regionalna kancelarija za Jugoistočnu Evropu, 2008), 384.

14 Toril Moi, "Feminist, Female, Feminine”, u: Catherine Belsey and Jane Moore, eds., The Feminist Reader. Essays in Gender and the Politics of Literary Criticism (New York, 1989), 117.

15 Ibid., 121. 
Pojmove "žensko" i "feminističko" možemo posmatrati ne samo u njihovom međusobnom odnosu, već i u odnosu prema pojmovima koji su im često suprotstavljeni. Mislim na činjenicu da se "žensko" tradicionalno shvata kao suprotnost "muškom", kao što priroda stoji naspram kulture, to jest, objašnjava se preko poznate dihotomije privatno/javno, u kojoj se privatno odnosi na "žensko", a javno na "muško". Naravno, savremena antropologija, kao i druge oblasti, prave razliku između pola i roda, pa tako danas znamo da "žensko" (i "ženstveno") nije određeno biologijom, već je ono društveni konstrukt, proizvod kognitivnih kulturnih modela. ${ }^{16}$ Ipak, odnos ženskog i feminističkog prema pojmovima koji su im tradicionalno suprotstavljeni nije tako jednostavan. Kako Toril Moi tvrdi: "biološka opozicija muško/žensko (...) koristi se da bi se konstruisao čitav niz negativnih ‘ženstvenih' vrednosti, koje se zatim nameću pojmu ‘ženskog' i mešaju sa njim." ${ }^{17}$ Upravo takav niz binarnih suprotnosti nalazimo kod Elen Siksu (Hélène Cixous) u tekstu pod naslovom "Gde je ona" ("Where is she"):

aktivnost/pasivnost
sunce/mesec
kultura/priroda
dan/noć
otac/majka
glava/srce
razum/osećajnost
logos/patos
$(. . .)^{18}$

Iz navedenog vidimo da se "žensko" shvata stereotipno, kao negativno i pasivno, naspram pozitivnih, aktivnih karakteristika "muškosti”. Dakle, kada su u pitanju sličnosti i razlike u značenju pojmova "žensko" i "feminističko", možemo da zaključimo da se oni ne mogu izjednačiti: sve što je žensko nije nužno i feminističko; i obrnuto, fe-

16 Više o tome u: Žarana Papić, Polnost $i$ kultura: telo i znanje u socijalnoj antropologïi (Beograd: XX vek, 1997).

17 Toril Moi, "Feminist, Female, Feminine", u: Catherine Belsey and Jane Moore, eds., The Feminist Reader. Essays in Gender and the Politics of Literary Criticism. (New York, 1989), 124.

18 Hélène Cixous, "Sorties: Out and Out - Attacks/Ways Out/Forays", u: Catherine Belsey and Jane Moore, eds., The Feminist Reader. Essays in Gender and the Politics of Literary Criticism (New York, 1989), 101-2. 
minističko delovanje nije rezervisano samo za žene. Međutim, ono što je ovim pojmovima zajedničko jeste njihova negativna percepcija koja se proizvodi i nameće u okviru patrijarhalnog sistema vrednosti.

U kontekstu časopisa ProFemina, koji se ubraja u jugoslovensku feminističku štampu s kraja dvadesetog i početka dvadeset i prvog veka, (ne)upotrebljavanje ova dva pojma posebno je zanimljivo. Razmatranje ambivalentnog stava časopisa ProFemina prema feminizmu može početi već od samog podnaslova. Naime, kako kaže Dubravka Đurić, jedna od urednica prvog broja ProFemine:

U periodu koncipiranja došlo je do neslaganja povodom toga da li to treba da bude feministički ili samo književni časopis, te je ponuđeno kompromisno rešenje podnaslovom koji kaže da je reč o ženskom časopisu za književnost i kulturu. Ta relativno neutralna, ili bar dvosmislena odrednica omogućila je raspon uređivačkih politika od onih koje insistiraju na književnosti autorki, koje su u književnom kanonu i u uredništvima časopisa marginalizovane (ova pozicija naizgled isključuje feminizam, ali ju je feminizam omogućio) do pozicija koje su u najeksplicitnijem smislu feminističke. ${ }^{19}$

Ovde treba istaći da je podnaslov časopisa ProFemina "časopis za žensku književnost i kulturu”. Ipak, to što ga Đurić naziva "ženskim časopisom" (umesto "časopisom za žensku književnost”) sugeriše da je u njemu objavljivana književnost koju su birale žene (ali ne nužno $\mathrm{i}$ isključivo književnost koju su žene pisale). Iako je naizgled reč o nijansi, ona je ključna sa stanovišta odnosa moći. Moć se ogleda u mogućnosti da se odlučuje o tome šta će biti objavljeno. Dubravka Đurić u svom uvodniku u prvom broju ProFemine s pravom pita: "Koliko žena utiče na donošenje takvih odluka?", ${ }^{20}$ i zaključuje da je njihov broj zanemarljiv. Kao što vidimo, izbor reči nije nimalo slučajan, već je od suštinskog značaja za uređivačku politiku časopisa.

Štaviše, iako je izabrana, kako Dubravka Đurić kaže, neutralna ili dvosmislena odrednica, u datom društvenom kontekstu odrednica "žensko" nije neutralna i pre bi se mogla definisati kao višeznačna. Naime, pored književnosti marginalizovanih autorki i feminističke književnosti, koju uredništvo ProFemine želi da stavi u prvi plan, pojam ženske književnosti devedesetih godina jednako označava i one

19 Dubravka Đurić, "Feministički i ženski časopisi u postjugoslovenskim kulturama”, ProFemina, specijalni broj, leto-jesen 2011, 269.

20 Dubravka Đurić, “Glasovi drugih”, ProFemina, broj 1, zima 1994/1995, 11-12. 
autorke koje u svojim delima koriste dominantne, patrijarhalne i nacionalističke motive, pa ne samo što nisu bile marginalizovane, već su bile veoma popularne i vidljive $\mathrm{u}$ javnom prostoru, a njihovi romani se pojavljuju u visokim tiražima. Da ponovim, "žensko" svakako ne mora biti i feminističko, pod "ženskim" se može izdavati i nešto što preuzima kulturne modele "muškog”, pa se izbor baš te odrednice za podnaslov časopisa može videti i kao pokušaj osvajanja prostora, preuzimanja i redefinisanja odrednice "žensko", iz perspektive koja nije dominantna, "muška" pozicija. Istovremeno, ta pozicija nije neutralna i, kako Dubravka Đurić ističe, omogućio ju je feminizam.

\section{JEDNAKOST ILI RAZLIKA?}

Poput rasprave o značenjima pojmova "žensko" i "feminističko", i rasprava o odnosu privatne i javne sfere, te jednakosti odnosno različitosti, dugo je prisutna i još uvek živa u feminističkim (akademskim) krugovima. Brojne i različite feminističke tradicije često imaju drugačije razloge kada se zalažu za jednakost žena i/ili, pak, insistiraju na razlici. Međutim, pitanja koja se uvek nameću jesu: “Jednaka kome?” i "Različita od čega?"

U kontekstu srpskih prilika, u zborniku Ka vidljivijoj ženskoj istoriji. Ženski pokret u Beogradu 9o-ih, Marina Blagojević primećuje:

Jedan od paradoksa ženskog pokreta jeste upravo u tome što se on veoma teško određuje prema tome koliko zapravo želi da žene budu različite u odnosu na muškarce. On je uvučen u sopstvenu protivrečnost između dve priče koje teku paralelno, od kojih je prva zapravo "pohvala ženama" i njihovoj različitosti, a druga insistiranje na priči “žene-žrtve". ${ }^{22}$

Ovaj paradoks primećujemo i u uređivačkoj politici časopisa $\mathrm{ProFe}$ mina. S jedne strane, u ovom časopisu žena je ta koja sa uređivačkih i kritičkih pozicija određuje šta je dobro. Drugim rečima, formalna jednakost uspostavljena je na osnovu odnosa moći svojstvenih patrijarhalnom sistemu vrednosti. S druge strane, insistira se na sopstvenoj marginalnosti, na potlačenosti žena u svim sferama društva, što

21 Gisela Bock i Susan James, "Introduction: Contextualizing equality and difference”, u: Gisela Bock and Susan James, eds., Beyond Equality and difference (Taylor \& Francis e-Library, 2005), 4.

22 Marina Blagojević, prir., Ka vidljivijoj ženskoj istoriji. Ženski pokret u Beogradu 9o-ih (Beograd: Centar za ženske studije, istraživanja i komunikaciju, 1998), 26. 
se vidi kao posledica odnosa moći koje diktiraju muškarci, odnosno patrijarhalno društvo. Takva situacija, naravno, nije svojstvena samo uredništvu časopisa ProFemina. Baš ta činjenica da je jednakost definisana unutar i preko postojećih muških odnosa, to jest, da se teži jednakosti pod muškim uslovima, a da se pozivanje na žensku različitost koristi za opravdanje polne/rodne nejednakosti, prepoznata je kao jedan od razloga neslaganja među feministkinjama. ${ }^{23}$ Šta uredništvo ProFemine želi da postigne svojom uređivačkom politikom: istupanje žena sa margine u zajednički prostor u kom bi stvarale zajedno sa muškarcima ili stvaranje novog prostora za žene? Ukoliko je cilj zajednički prostor jednakosti, da li je ta jednakost definisana postojećim ili novim principima? Ovako piše Ljiljana Đurđić, jedna od urednica:

Pokretanje ženskog književnog časopisa (...) predstavlja svakako strategiju za osvajanje i širenje kulturnog prostora, za menjanje/diktiranje ukusa, uvođenje ženske perspektive u književne poslove, pretvaranje žene objekta u ženu subjekat, uništavanje modela svetice, majke i ortodoksne kurve koji su prevashodno muški, i stvaranje novih, autentično ženskih modela "pevanja i mišljenja". Istovremeno to je i insistiranje na različitosti u jednakosti koja dozvoljava sebi i da arbitrira ne polazeći od postavke da je sve što napišu žene unapred vredno pažnje. U tom smislu, svako "muško pismo" je dobrodošlo uz istu dozu probirljivosti koja je ovog puta, za promenu, u ženskim rukama. ${ }^{24}$

Dakle, ProFemina ne samo da želi da "doda” žensko, marginalizovano stvaralaštvo u postojeći kulturni prostor, već bi da menja taj prostor, da ga širi i preoblikuje. Pozicija sa koje to može da uradi jeste ona iznutra, koristeći se delimično muškim strategijama i sredstvima.

Marginalizovana grupa ljudi, koju časopis ProFemina predstavlja, ne želi da ostane na margini. U svom uvodniku u prvom broju časopisa, Radmila Lazić piše:

Nećemo geto, ali nećemo ni marginu.

Nismo za segregaciju ni za rat polova.

23 Gisela Bock i Susan James, "Introduction: Contextualizing equality and difference", u: Gisela Bock i Susan James, eds., Beyond Equality and difference (Taylor \& Francis e-Library, 2005), 3.

24 Ljiljana Đurđić, "Nova / stara strategija ili žene ponovo dolaze”, ProFemina, broj 1, zima 1994/95, 15 . 


\section{(...) \\ Nećemo paralelni svet i paralelnu kulturu. \\ Hoćemo isti prostor u koji ćemo upisivati svoje NE. NE posto- jećem svetu / što je konstanta svakog pisanja / i NE normama, standardima i konvencijama koje su propisali muškarci. ${ }^{25}$}

Na osnovu ovog uvodnika možda se može najbolje razumeti neutralnost odrednice “ženski”, koju je pominjala Dubravka Đurić. Drugim rečima, (hipotetički) izbor pojma "feministički" za podnaslov časopisa možda bi upućivao na odsustvo ambicije autorki i autora koji će u časopisu objavljivati da izađu sa margine, odnosno na težnju ka getoizaciji, stvaranju paralelne kulture i odvojenog prostora u kom će se oni slobodno izražavati. Takav stav uredništva - da žele da ravnopravno učestvuju u istom prostoru, od velikog je značaja jer je "strah od izolacije izuzetno čest upravo kod žena" ${ }^{26}$ Međutim, taj strah nije izbegnut upotrebom odrednice "ženski" umesto "feministički”. U uvodniku u prvom broju Dubravka Đurić insistira da časopis ProFemina ne predstavlja sam po sebi marginalizaciju, ali navodi da su mnoge potencijalne saradnice u procesu uređivanja prvog broja zazirale od saradnje sa ProFeminom plašeći se upravo marginalizacije. ${ }^{27}$ Kada objašnjava strah od izolacije, Biljana Dojčinović zaključuje:

Pojmovi "feminizam", "feministkinja" i pridev "feministički" jesu, dakle, kvalifikacije od kojih se treba odbraniti da bismo mi same i naš rad bili prihvaćeni u društvu i javnosti i spasene od izolacije. Kao i sve predrasude i stereotipi, unapred preuzeti i neprovereni negativni stavovi, i predrasude o ovim pojmovima uporne su i dugog veka. ${ }^{28}$

Na kraju, kao element uređivačke politike ProFemine Svetlana Slapšak vidi i ideju fragmentacije kulture (koja ne znači marginalizaciju) naspram ideje kulture totaliteta. Slapšak postavlja pitanje o zajedničkom odnosno odvojenom prostoru kulturnog delovanja:

25 Radmila Lazić, “Jednakost / u / različitosti”, ProFemina, broj 1, zima 1994/95, 13. 26 Biljana Dojčinovoć-Nešić, "Feminizam: predrasude, stereotipi i negativni stavovi”, u: Marina Blagojević, prir. Mapiranje mizoginije u Srbiji: diskursi i prakse (Beograd: AŽIN, 2000), 619-620.

27 Dubravka Đurić, “Glasovi drugih”, ProFemina, broj 1, zima 1994/1995, 11-12. 28 Ibid. 
Postojanje "niša” podrazumeva ne izolaciju, već poroznost. Šta više želite? Univerzitet i kulturu sa prevlađujućim idejama, licima i govorom, i marginalizovanu alternativu, ili univerzitet i kulturu sa školama mišljenja koje se možda ne podnose, ali se ne isključuju, i koje za sebe ostvaruju svoj prostor, i alternativu koja se na državnim jaslama nadmeće sa zvaničnim institucijama? ${ }^{29}$

Urednice u uređivačkoj politici ProFemine polaze od stanovišta da ne žele da ostanu na margini. Takvo opredeljenje primećujemo tokom čitavog perioda izlaženja ovog časopisa. Kada kritikuje shvatanje kulture kao totaliteta, cilj uredništva nije puko preuzimanje muškog prostora i zamenjivanje jednog totaliteta drugim, već stvaranje kulture koja je fragmentisana, koja dopušta i propušta razlike u kulturnom prostoru, te prihvata različita mišljenja (naravno, ne pušta u taj prostor "fašiste, rasiste, seksiste, monarhiste, verske manijake") ${ }^{30} \mathrm{i}$ tako sprečava prisilnu marginalizaciju različitih škola mišljenja.

\section{O FEMINISTIČKOM ZNANJU}

Čak i da je u podnaslovu časopisa napravljen kompromis, u sadržaju uvodnika takvog kompromisa svakako nema. U uvodnicima se vidi nedvosmisleno i direktno opredeljenje za feminizam i pacifizam. Prvi broj časopisa otvaraju uvodnici četiri urednice - pored već pomenutih uvodnika Dubravke Đurić i Radmile Lazić, na početku prvog broja nalaze se i uvodnici Svetlane Slapšak i Ljiljane Đurđić. Prvi uvodnik napisala je glavna i odgovorna urednica Svetlana Slapšak, pod naslovom “Ženskom rukom - šta?". Za ovaj uvodni tekst ne može reći se da je neutralan ili dvosmislen. Slapšak već u prvom pasusu, oštrim i ironičnim tonom, stavlja do znanja da ce ProFemina objavljivati tekstove o feminizmu. Osvrnuvši se na časopis Ženske studije, koji se osniva u isto vreme i konkuriše za ista sredstva, ${ }^{31}$ Slapšak piše:

ProFemina se specijalizuje za žensku kulturu i književnost, za istoriju feminizma, ženske književnosti i ženskog pisma, za kritiku, prevodilaštvo i informacije iz tih oblasti. Za drugi ženski

29 Svetlana Slapšak, "Naše polemike”, ProFemina, broj 23/24, jesen/zima20oo, 15-16. 30 Ibid.

31 Dubravka Đurić, "Feministički i ženski časopisi u postjugoslovenskim kulturama”, ProFemina, specijalni broj, leto-jesen 2011, 271. 
časopis, koji sledi, ostaje ogromno područje teorije feminizma, davanje potpore ženskim studijama i ženskim pokretima: možemo se nadati da će se dva časopisa često poklapati u zanimanjima ili inicijativama, i da će se buduće saradnice oba časopisa osećati dobro ako se oko njihove naklonosti budu trudile dve redakcije. ${ }^{32}$

Iz ovakvog uvoda proizlazi da je uređivačka politika ProFemine jasno feministička: ženska književnost je postojala i ranije, ali ono što je nedostajalo i što ProFemina donosi jeste žensko uredništvo, kao i kritika koja će žensku književnost birati, tumačiti i preporučivati. Osim toga, Svetlana Slapšak ističe da je mnogo neistraženih tema koje se tiču ženskog znanja; samim tim, ima dovoljno prostora za saradnju i/ili međusobno dopunjavanje dva časopisa. Dva časopisa ne samo da nisu bila međusobno suprotstavljena, već nisu ni dovoljna za suprotstavljanje u polju "nevidljivosti" koja je nametnuta ženama u kulturnim institucijama i krugovima. ${ }^{33}$ Najzad, naslov ovog uvodnika, “Ženskom rukom - šta”, sugeriše najmanje dve stvari: nije svaka književnost koju su napisale žene feministička; potrebno je da se žene nađu na odlučujućim pozicijama - kao urednice i kritičarke, te da sa tih pozicija utiču na ponovno vrednovanje književnosti i preispitivanje zadatih odnosa moći u polju kuture i obrazovanja. Feminizam je eksplicitan kako u uvodnicima tako i u rubrikama u ProFemini, bilo da je reč o istraživanju prošlosti (npr. "Portret prethodnice"), bilo da je reč o savremenoj književnoj produkciji, kao i književnoj kritici. Kulturna i književna istorija čitaju se i pišu iznova u ovom časopisu.

\section{NEVOLJE S FEMINIZMOM}

Najzad, pošto smo razmotrili zašto se osnivačice časopisa ProFemine opredeljuju za odrednicu "ženski" umesto "feministički”, i opisali prostor koji urednice žele kreiraju i osvoje, treba razmotriti šta je to što feminizam čini tako problematičnim pojmom, odnosno idejom, te daje povoda da se uredništvo ProFemine, po stavovima jasno feministički profilisano, odluči za kompromis i izbegne reč feminizam u svom (pod)naslovu.

Negativna stereotipizacija feminizma na postjugoslovenskom prostoru delom je rezultat komunističkog nasleđa, odnosno shvatanja fe-

32 Svetlana Slapšak, “Ženskom rukom - šta?”, ProFemina, broj 1, zima, 1994/95, 11-12.

33 Ibid. 
minizma kao buržoaskog ženskog pokreta. Novinarka i feministkinja Lina Vušković piše ovako 1983. godine:

Feminizam kao svetski pokret diskredituje se čak i u našoj najozbiljnijoj štampi. U svim mogućim tonovima, od onog šaljivog i ironičnog, preko zajedljivog, do krajnje ozbiljnog, teorijskog razmatranja i osuda... Na adresu već same reči FEMINIZAM toliko je kod nas toga pristiglo, da nije redak slučaj da, kada se pomene, kod mnogih izaziva "ospe" čak iako se u suštini slažu sa onim što feminizam zapravo jeste. ${ }^{34}$

Kao glavne stereotipe o feminizmu, Biljana Dojčinović navodi odsustvo ženstvenosti, feminističku opasnost, uvezenu građansku ideologiju i rat polova. ${ }^{35}$ Međutim, ovom spisku stereotipa nastalih u socijalizmu treba dodati niz kvalifikacija koje se feminizmu pripisuju $\mathrm{u}$ ratnom kontekstu devedesetih godina (razume se, uz kritičku distancu, jer socijalizam i nacionalizam nipošto ne treba izjednačavati). ${ }^{6} \mathrm{U}$ javnom diskursu 90-ih godina feministkinje se proglašavaju "nacionalnim neprijateljima", "antiratnim profiterima", "fašistima". Upravo kulturni totalitet nacionalizma, koji pominje Svetlana Slapšak, ima stalnu potrebu za "mrskim neprijateljem na domak ruke"; te neprijatelje nacionalizam pronalazi u onima koji mu se protive, a to su, skoro po pravilu, marginalizovane grupe. ${ }^{37}$ Uloga neprijatelja feministkinjama je lako dodeljena, pa ne čudi što su i pored ekspanzije ženskog pokreta,

iskazi u kojima su pojmovi "feminizam", "feminist(kinj)a”, i "feministički” oslobođeni ideološkog i psihološkog balasta nepristojnosti i upotrebljeni u afirmativnom značenju još uvek (...) retki i mogu se čuti samo od manjeg broja žena i muškaraca, uglavnom u posebnim prilikama. ${ }^{38}$

34 Citirano prema: Biljana Dojčinović-Nešić, "Feminizam: predrasude, stereotipi i negativni stavovi”, u: Marina Blagojević, prir., Mapiranje mizoginije u Srbiji: diskursi i prakse (Beograd: AŽIN, 2000), 623.

35 Ibid., 624.

36 Žarana Papić, "Od državnog socijalizma do državnog nacionalizma: slučaj Srbije iz rodne perspektive”, u: Adriana Zaharijević, Zorica Ivanović i Daša Duhaček, ur., Žarana Papić, Tekstovi 1977-2002 (Beograd, 2012), 287-302.

37 Svetlana Slapšak, “Ženskom rukom - šta?”, ProFemina, broj 1, zima, 1994/95, 11. 38 Biljana Dojčinović-Nešić, "Feminizam: predrasude, stereotipi i negativni stavovi”, u: Marina Blagojević, prir., Mapiranje mizoginije u Srbiji: diskursi i prakse (Beograd: AŽIN, 2000), 629. 
Biljana Dojčinović opisuje standardne stereotipizacije u vezi sa feminizmom kao:

agresivan ženski stav prema muškarcima, težnju da se ostvari premoć, odbacivanje "prirodne" (normalne) ženske uloge, pre svega materinstva, [vezanog] za fizički ružnu (neženstvenu) ženu, sebičnu ženu, zainteresovanu pre svega ili isključivo za sopstveni uspeh, a uz to i ženu sumnjivih seksualnih sklonosti....39

Marina Blagojević ide korak dalje i, koristeći lični primer, pokazuje da strah i zaziranje od feminizma proizlazi iz stava okoline da feministkinje "znaju šta rade", kao da to, kako Blagojević primećuje, podrazumeva neku "pokvarenost i predumišljaj", ${ }^{40}$ te odbijaju da ostanu na margini i tako remete poredak koji odgovara onima na poziciji moći.

Dok razmatra istoriju feminizma u kratkim crtama, Ljiljana Đurđić se u svom uvodniku u prvom broju pita "da li je feminizam najbolji oblik ženskog organizovanja s obzirom da, kako je primetila Margarit Jursenar, retko daje rezultate na duže staze, a po svojoj biti je konformističan jer održava postojeći poredak" ${ }^{41}$ Prema Đurđić, feminizam, iako često kompromitovan, predstavlja "jedini organizovani oblik ženske borbe za ravnopravnost među polovima i jednaki društveni tretman i kao takav za sada je nezamenljiv". ${ }^{42}$

\section{ZAKLJUČAK}

Uprkos razlikama između pojmova "ženski” i "feministički”, i jedan i drugi pojam se u javnom diskursu pretežno definišu kao nešto negativno, nešto što izaziva strah i podozrenje. Pošto je uredništvo ProFemine bilo protiv svih oblika marginalizacije i getoizacije, a žensko stvaralaštvo je u datom kontekstu već bilo skrajnuto, sva je prilika da su urednice kompromisom u podnaslovu, to jest definisanjem ProFemine kao "časopisa za žensku književnost i kulturu” umesto kao "feminističkog časopisa", želele da izbegnu dodatnu marginalizaciju, te da uvere one koji će u časopisu objavljivati da će biti posvećene me-

39 Ibid., 624.

40 Marina Blagojević, “Tri slučaja feminista”, u: Marina Blagojević, prir., Mapiranje mizoginije u Srbiji: diskursi i prakse (Beograd: AŽIN, 2000), 633-637.

41 Ljiljana Đurđić, “Nova / stara strategija ili žene ponovo dolaze”, ProFemina, broj 1, zima 1994/95, 14.

42 Ibid. 
njanju i širenju postojećeg kulturnog prostora. Ambivalentan odnos prema feminizmu, osim što proizlazi iz želje da se izbegne getoizacija, može se objasniti i negativnim stereotipima o feminizmu koji su se devedesetih godina razvili do neslućenih razmera. Nacionalistički i patrijarhalni kulturni totalitet vidi žene/feministkinje kao dežurne krivce. Zbog toga, čak i one žene koje se suštinski zalažu za ženska/ feministička pitanja osećaju potrebu da se od feminizma ograde da njihov rad ne bi bio skrajnut. Samim tim, one se zalažu za vrednovanje njihovog rada u okviru postojećeg kulturnog prostora. Časopis ProFemina nastavlja feminističku tradiciju, odbacujući neutralnu poziciju, zauzimajući jasan stav koji je feministički, antinacionalistički, antifašistički, pacifistički, suprotstavljen mizoginiji i patrijarhalnom poretku. Takvo opredeljenje podrazumevalo je odbijanje bilo kakvog totaliteta i težnju ka fragmentisanom javnom prostoru, u kom se iznova otkrivaju i vrednuju ženska i feministička prošlost, odnosno žensko i feminističko stvaralaštvo.

\section{LITERATURA}

Belsey, Catherine, Moore, Jane, eds. The Feminist Reader. Essays in Gender and the Politics of Literary Criticism (New York, 1989).

Blagojević, Marina, prir. Ka vidljivijoj ženskoj istorïi. Ženski pokret u Beogradu 9o-ih (Beograd: Centar za ženske studije, istraživanja i komunikaciju, 1998).

Blagojević, Marina, prir. Mapiranje mizoginije u Srbiji: diskursi i prakse (Beograd: AŽIN, 2000).

Bock, Gisela, James, Susan, eds. Beyond Equality and Difference (Taylor \& Francis e-Library, 2005).

Dimitrijević, Nenad. "Moralne osnove izgradnje mira". Reč, časopis za književnost i kulturu, i društvena pitanja, broj 87/33, 2017, 3-12.

Đurić, Dubravka. "Feministički i ženski časopisi u postjugoslovenskim kulturama”. ProFemina, specijalni broj, leto-jesen 2011, 263-282.

Milinković, Jelena. "Profemina: interkulturalizam i jugoslovenski feminizmi”. U: Roksandić, Drago, ur. Hrvatsko-srpski/srpsko-hrvatski interkulturalizam danas: zbornik radova (Zagreb: Filozofski fakultet Sveučilišta u Zagrebu, 2017), 127-138.

Papić, Žarana. Polnost i kultura: telo i znanje u socijalnoj antropologiji (Beograd: XX vek, 1997). 
Powell, Manushag N. "Afterword: We Other Periodicalists, or, Why Periodical Studies?”. Tulsa Studies in Woman's Literature, Volume 30, Number 2, Fall 2011, 441-450.

Zaharijević, Adriana, prir. Neko je rekao feminizam? Kako je feminizam uticao na žene XXI veka (Beograd : Heinrich Böll Stiftung, Regionalna kancelarija za Jugoistočnu Evropu, 2008).

Zaharijević, Adriana, Ivanović, Zorica i Duhaček, Daša, ur. Žarana Papić, Tekstovi 1977-2002 (Beograd, 2012).

\section{UVODNICI}

Đurđić, Ljiljana. "Nova / stara strategija ili žene ponovo dolaze". ProFemina, broj 1, zima 1994/1995, str. 14-15.

Đurić, Dubravka. "Glasovi drugih". ProFemina, broj 1, zima 1994/1995, str. 11-12.

Lazić, Radmila. “Jednakost / u / različitosti”. ProFemina, broj 1, zima 1994/1995, str. 13.

Slapšak, Svetlana. "Ženskom rukom - šta”. ProFemina, broj 1, zima 1994/1995, str. 11-12.

Slapšak, Svetlana. "Polites, Patriotes”. ProFemina, broj 9/10, zima/ proleće 1997, str. 11-12.

Slapšak, Svetlana. "Postavimo granice". ProFemina, broj 11, jesen 1997, str. 11-14.

Slapšak, Svetlana. "Kolateralna korist”. ProFemina, broj 17-20, proleće-zima 1999, str. 11-16.

Slapšak, Svetlana. "Naše polemike". ProFemina, broj 23/24, jesen/ zima 2000, str. 11-16.

Slapšak, Svetlana. "Procenjivanje, o sedmogodišnjici". ProFemina, broj 27/28, jesen/zima 2001, str. 11-14.

Slapšak, Svetlana. "Izlaz iz prisilne arhaizacije”. ProFemina, broj 33/34, jesen/zima 2003, str. 11-13.

Slapšak, Svetlana. "Deset godina ProFemine". ProFemina, broj 35/36, proleće/leto 2004, str. 11-13.

Slapšak, Svetlana. “Dosta misoginije!”. ProFemina, broj 37-40, jesen/ zima 2004 - proleće/zima 2005, str. 11-14. 


\section{ON FEMINISM IN THE EDITORIALS OF JOURNAL "PROFEMINA"}

This paper aims to describe the attitude ProFemina journal, that is, its editors and associates have towards feminism. More precisely, this paper discusses the meaning of the terms "feminism" and "female" in the ProFemina editorials, as well as in the journal subtitle itself. The paper analyzes the editorials appearing in all of the issues, with particular attention to the editorials in the first issue of the journal in which the four editors (Svetlana Slapšak, Radmila Lazić, Ljiljana Đurđić and Dubravka Đurić) articulate their attitude towards these terms. The views expressed in the editorials have been placed in a broader context of social and historical circumstances in which the journal was founded. Based on the editorial policy of the journal, as well as the circumstances in which the journal came out, it can be concluded that its specific attitude towards feminism aims to make marginalized authorship visible, both by conquering and by changing the existing public space.

Keywords: ProFemina, feminism, women's literature, politics of editing 